\title{
FITOREMEDIASI KOLAM PEMELIHARAAN IKAN DENGAN MEMANFAATKAN SAYURAN
}

\author{
Nuryadi, Sutrisno, dan Dewi Puspaningsih \\ Balai Riset Perikanan Budidaya Air Tawar \\ J.. Raya Sempur No. 1, Bogor \\ E-mail: nursudarman@gmail.com
}

\begin{abstract}
ABSTRAK
Limbah domestik yang mengandung $\mathrm{N}$ dan $\mathrm{P}$ apabila kadarnya melebihi kemampuan perairan untuk mengurainya, akan memicu pertumbuhan organisme tertentu secara berlebihan dan mengakibatkan ketidakseimbangan ekosistem perairan. Kondisi tersebut apabila tidak ditanggulangi akan mengakibatkan menurunnya kualitas perairan yang akan menurunkan produktivitas dan keanekaragaman hayati perairan tersebut. Arah pembangunan perikanan budidaya air tawar mulai berubah ke arah peningkatan efisiensi penggunaan lahan dan air untuk memproduksi ikan bersih dan sehat dikonsumsi. Teknik fitoremediasi terbukti mampu mengurangi penggunaan lahan dan air dalam kolam sistem tertutup, selain resirkulasi pada sistem akuaponik. Teknik fitoremediasi lebih hemat energi dibanding sistem akuaponik yang kerjanya sangat tergantung dari kerja pompa air, sehingga penggunaan sistem ini dapat mencakup daerah yang lebih luas, terutama di daerah yang belum terjangkau listrik. Fitoremediasi juga dapat memberikan andil dalam pemenuhan pangan yang sehat dengan menghasilkan ikan dan sayuran organik yang bermanfaat.
\end{abstract}

\section{KATAKUNCl: limbah domestik, efisiensi lahan dan air, fitoremediasi}

\section{PENDAHULUAN}

Permasalahan yang dihadapi dalam pengelolaan perairan di daratan selain berakar pada gejala alam, juga dapat bersumber dari aktivitas antropogen seperti dampak kegiatan pertanian dan pemukiman serta dampak kumulatif dari perubahan tata ruang di hulu dan di daerah aliran sungai (DAS). Dampak langsung yang diakibatkannya adalah turunnya kualitas kimia dan fisika air, serta dampak tidak langsung adalah turunnya kemampuan daya dukung ekosistem untuk mendukung produktivitas perairan. Di antara berbagai kerusakan ekosistem, empat dampak limnologis akibat turunnya daya dukung perairan adalah (a) berkurangnya produksi perikanan, (b) tumbuhnya gulma, (c) tercemarnya sumber air dan plasma nutfah, (d) pendangkalan danau yang mengakibatkan kendala transportasi air pada musim kemarau dan banjir pada saat hujan (Haryani \& Hehanussa, 2002).

Limbah domestik merupakan salah satu sumber pencemar yang sangat potensial terutama di daerah perkotaan dan padat penduduk. Limbah tersebut berasal dari aktifitas manusia dalam memenuhi hajat hidupnya, pada umumnya limbah organik baik berupa limbah cair maupun padat, yang banyak mengandung unsur nitrogen (N) dan fosfat (P).

Unsur $\mathrm{N}$ dan $\mathrm{P}$ yang masuk ke perairan, apabila melebihi kemampuan perairan untuk mengurainya akan meningkatkan kesuburan perairan, yang memicu pertumbuhan organisme tertentu secara berlebihan, sehingga akan menekan organisme lainnya. Hal ini mengakibatkan terjadinya ketidakseimbangan ekosistem di perairan tersebut. Kelebihan unsur $\mathrm{N}$ dan $\mathrm{P}$ pada badan air (sungai, danau, dan waduk) yang sumber utama pasokan airnya berasal atau melalui daerah pemukiman padat penduduk atau daerah pertanian yang sangat intensif seringkali terjadi. Kondisi seperti ini apabila tidak ditanggulangi akan mengakibatkan menurunnya kualitas air, yang pada akhirnya akan menurunkan produktivitas dan keragaman hayati perairan tersebut (Sutrisno et al., 2006).

Dengan mempertimbangkan persaingan penggunaan lahan yang terus makin ketat, sumberdaya air yang makin kritis, peningkatan kerusakan sumberdaya dan lingkungan perairan, kesadaran masyarakat akan arti penting lingkungan dan pangan sehat, penerapan sanksi terhadap pelanggaran Undang-Undang Nomor 11 Tahun 1974 dan Undang-Undang Nomor 7 Tahun 2004 tentang Sumberdaya Air, serta kepedulian institusional dan politik yang lemah. Arah pembangunan perikanan budidaya air tawar sudah harus berubah ke peningkatan efisiensi penggunaan lahan 
dan air untuk memproduksi ikan bersih dan sehat dikonsumsi, sebagai sumber protein yang terjangkau oleh berbagai lapisan masyarakat dalam suatu upaya pengelolaan sumberdaya secara terintegrasi (Integrated resources management/IRM ). Perikanan budidaya air tawar sudah harus menjadi salah satu bagian dari berbagai upaya pemeliharaan dan indikator pelestarian lingkungan perairan (Ahmad, 2006).

Fitoremediasi layak diterapkan dalam budidaya perikanan air tawar dalam kolam sistem tertutup selain resirkulasi pada sistem akuaponik yang terbukti mampu menghemat lahan dan air. Lebih lanjut fitoremediasi selain hemat energi juga dapat memberikan andil dalam pemenuhan pangan yang sehat dengan menghasilkan ikan dan sayuran organik berkualitas prima.

\section{BUDIDAYA IKAN SISTEM TERTUTUP DAN TERBUKA}

Budidaya ikan sistem tertutup yaitu pengairan untuk kolam pemeliharaan diberikan hanya satu kali saja yakni pada saat pemeliharaan akan dilaksanakan, pemasukan air berikutnya dilakukan hanya untuk mengganti air yang hilang karena penguapan saja. Contoh sistem ini adalah teknik akuaponik dan fitoremediasi. Sedangkan budidaya ikan sistem terbuka yaitu pengairan dilakukan secara terus-menerus selama pemeliharaan berlangsung. Contoh sistem ini adalah budidaya pada kolam mengalir dan air deras.

Dari beberapa penelitian membuktikan bahwa sistem tertutup pada budidaya ikan air tawar secara teknis lebih produktif, secara ekonomis lebih menguntungkan dan secara ekologis lebih dapat dipertanggungjawabkan dibanding sistem terbuka.

Jika terjadi wabah penyakit pada budidaya ikan sistem tertutup, kemungkinan akan lebih mudah diatasi karena penyakit tidak menyebar ke kolam lain. Sehingga kemungkinan terjadinya wabah penyakit yang lebih besar dapat lebih mudah dihindari dibanding dengan budidaya sistem terbuka.

Budidaya air tawar pada kolam air deras, secara nyata membuang hara yang diperlukan bagi pertumbuhan pakan alami keluar dari kolam pemeliharaan dan sekaligus menurunkan produktivitas kolam hingga hanya mampu menghasilkan 0,2 g ikan per $\mathrm{m}^{3}$ air (Suprayitno, 1986).

Ikan patin (Pangasiodon hypopthalmus) yang dipelihara pada kolam sistem mengalir hanya mampu menghasilkan 1,87--1,89 g ikan per $\mathrm{m}^{3}$, sedangkan pada kolam sistem tertutup atau resirkulasi dihasilkan 202,38--220,05 g ikan per $\mathrm{m}^{3}$ air dalam waktu 2 bulan (Ahmad et al., 2007).

\section{FITOREMEDIASI}

Instalasi Riset Perikanan Budidaya Air Tawar dan Toksikologi, Bogor telah mengembangkan penelitiannya pada budidaya ikan yang hemat lahan dan air, yaitu dengan melakukan budidaya ikan sistem kolam tertutup. Sistem kolam tertutup ini selain menggunakan resirkulasi air juga telah ditemukan teknik fitoremediasi, yaitu perbaikan kualitas air dengan memanfaatkan tanaman tingkat tinggi di antaranya sayuran. Akar tanaman/sayuran langsung masuk ke badan air untuk menyerap nutrien tersedia yang ada di dalam air, yang merupakan hasil perombakan limbah organik (misalnya: nitrat, amonium dan ortho fospat), sehingga tidak perlu pompa air untuk mendistribusikan air ke setiap tanaman seperti pada sistem akuaponik.

Fitoremediasi dapat diterapkan dengan cara menanam sayuran di keranjang plastik yang diisi dengan arang sebagai media. Keranjang dirangkai dengan pipa PVC yang sekaligus berfungsi sebagai pelampung sehingga rangkaian keranjang tadi menyerupai rakit yang terapung di atas permukaan air kolam.

Sayuran yang bisa digunakan adalah sayuran yang biasa hidup di air seperti kangkung (yang lain belum dicoba). Sebelum ditanam dalam keranjang, bibit sayuran terlebih dahulu disemai pada persemaian, seperti biasa petani lakukan.

Menurut Sutrisno et al. (2006), untuk memproduksi ikan dengan produk sampingan kangkung pada kolam tertutup yang ditebari 10 ekor ikan nila/m² dengan ukuran bobot rataan $10 \mathrm{~g} /$ ekor, sebaiknya luas penanaman kangkung maksimum $10 \%$ dari luas kolam $(P<0,05)$. Sedangkan jika tujuannya untuk memproduksi kangkung,

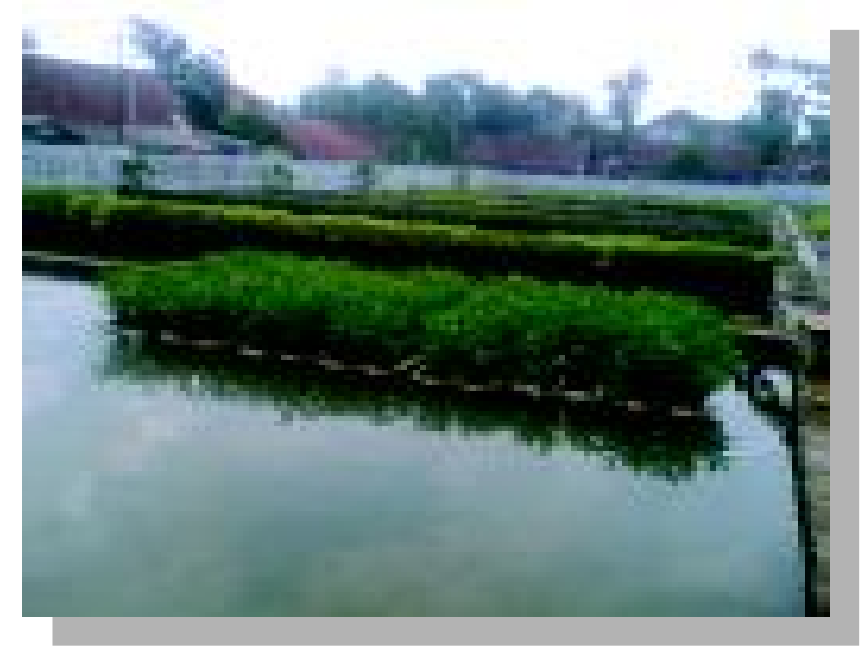

Gambar 1. Model fitoremediasi dengan menggunakan tanaman kangkung 

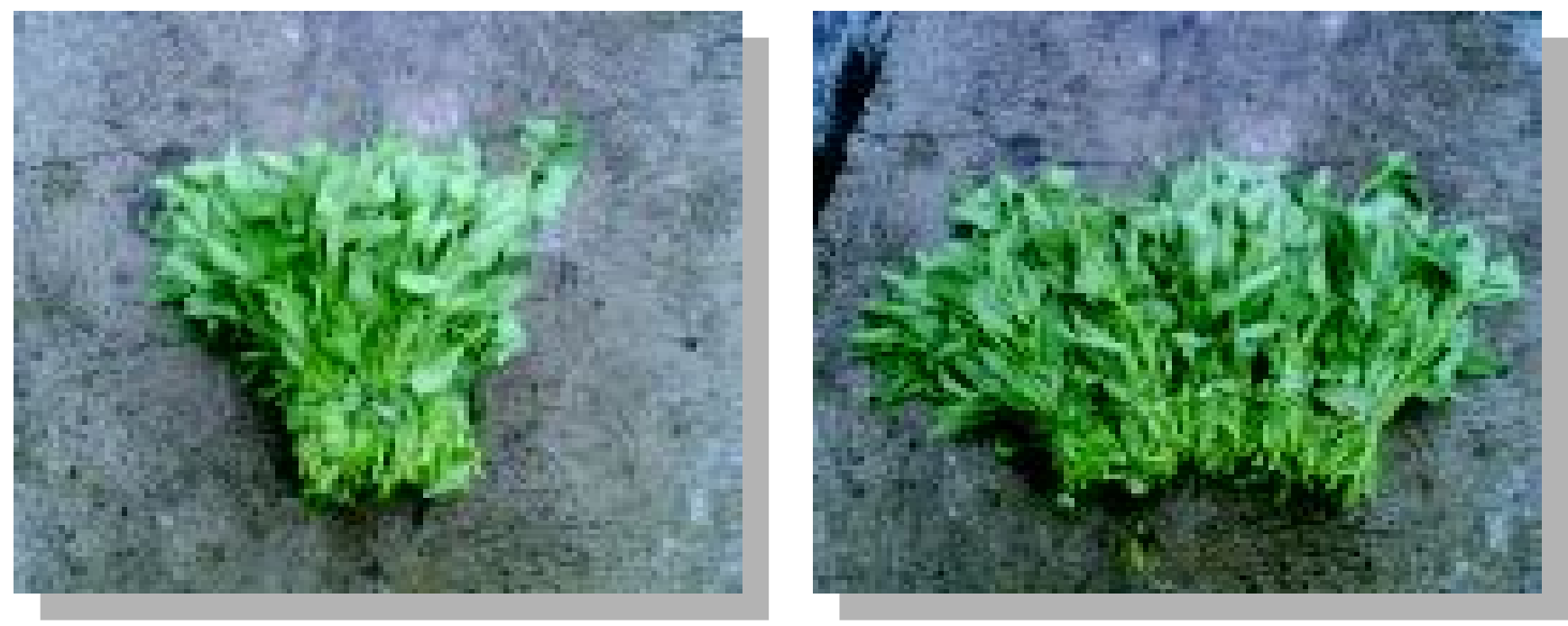

Gambar 2. Kangkung organik yang sangat digemari konsumen

produktivitas ikan akan turun secara nyata sampai luas penanaman kangkung 63\%dari luas kolam. Jika penanaman kangkung melebihi $63 \%$ produksi ikan kemungkinan akan stabil $(P<0,15)$. Lebih lanjut dikatakan, ikan nila yang dipelihara dalam kolam fitoremediasi dengan menggunakan kangkung seluas 10\%-30\%dari luas kolam, dipelihara ikan nila 10 ekor $/ \mathrm{m}^{2}$ dengan bobot rataan $10 \mathrm{~g} /$ ekor, diberi pakan berupa pelet komersial (protein 25\%) sebesar 3\%-4\%biomassa ikan/hari mempunyai sintasan yang tidak berbeda nyata dengan kolam yang tidak ditanami kangkung. Sistem ini mampu menghasilkan produktivitas kangkung rata-rata sebesar $6.594-7.150 \mathrm{~g} /$ $\mathrm{m}^{2} / 3$ minggu dan ikan nila 478,293--637,930 $\mathrm{g} / \mathrm{m}^{2} / 3$ bulan.

Teknik Fitoremediasi ini hanya sesuai pada kolam atau perairan yang benar-benar telah tercemar bahan organik, yaitu jika kandungan $\mathrm{NH}_{3}$ dan $\mathrm{NO}_{2}$ - lebih dari 0,65 dan $0,10 \mathrm{mg} \mathrm{L}^{-1}$ (Boyd et al., 1994; Cheng et al., 2002), jika tidak justru menyebabkan persaingan pemanfaatan nutrien dan kebutuhan cahaya matahari antara tanaman tingkat tinggi dan fitoplankton, akibatnya produktivitas ikan akan menurun.

Teknik fitoremediasi ini, akan lebih hemat energi dibanding teknik resirkulasi (akuaponik) yang sistemnya sangat tergantung dari kerja pompa air, sehingga penggunaan sistem fitoremediasi ini akan lebih mencakup daerah yang lebih luas, terutama di daerah yang belum terjangkau listrik.

Fitoremediasi mampu memanfaatkan limbah budidaya terutama kandungan $\mathrm{N}$ dan $\mathrm{P}$ yang berasal dari sisa pakan dan kotoran ikan, kemudian merubahnya menjadi produk sayuran organik, yaitu sayuran yang tidak atau hanya sedikit menggunakan pestisida dan pupuk buatan
(Anonimous, 2008). Lebih lanjut hal tersebut juga berdampak terpeliharanya lingkungan perairan dari limbah hasil budidaya perikanan, yaitu turut menekan laju eutrofikasi perairan.

\section{KESIMPULAN}

1. Fitoremediasi dengan menggunakan tanaman kangkung bisa dijadikan model dalam mengurangi pencemaran pada budidaya perikanan air tawar.

2. Penanaman kangkung yang diintegrasikan dengan kegiataan budidaya perikanan air tawar yang dilakukan secara tepat, tidak akan mencemari lingkungan, akan tetapi justru menjadi kegiatan yang dapat melestarikan lingkungan perairan dan menghasilkan produk pangan yang bermanfaat.

\section{SARAN}

1. Jika produksi kangkung hanya merupakan sampingan, sebaiknya luas penanaman tidak boleh lebih dari $10 \%$ dari luas kolam.

2. Teknik fitoremediasi hanya tepat diterapkan pada kolam atau perairan yang sudah tercemar bahan organik.

3. Panen kangkung sebaiknya dilakukan maksimal 3 kali per siklus tanam.

\section{UCAPAN TERIMA KASIH}

Kami sampaikan terima kasih yang sebesar-besarnya kepada almarhum Bapak Prof. Riset Dr. Taufik Ahmad atas bimbingan dan arahannya selama proses penelitian hingga terselesaikannya tulisan ini. 


\section{DAFTAR ACUAN}

Anonimous. 25 April, 2008. Makanan organik. Media Indonesia.

Ahmad, T., Sofiarsih, L., \& Kusmana. 2007. The growth of patin Pangasius hypopthalmus in a close tank. Indonesian Aquaculture Journal. 2(1): 67- 73.

Ahmad, T. 2006. Perikanan budidaya sebagai langkah maju pemanfaatan terkendali sumberdaya perairan. Orasi pengukuhan Profesor Riset. Departemen Kelautan dan Perikanan, Badan Riset Kelautan dan Perikanan, Jakarta. $82 \mathrm{hlm}$.

Boyd, C.E., Tanner, M.E., Madkour, M., \& Masuda, K. 1994. Chemical characteristic of bottom soils from freshwater and brackishwater aquaculture ponds. Journal of The World Aquaculture Society. 5(4): 15-21.

Cheng, W., Su-M ei Chen, Feng-I Wang, Peng-I Hsu, ChunHung Liu, \& Jian-Chu Chen. 2002. Effect of tempera- ture, $\mathrm{pH}$, salinity, and ammonia on the phagocytic and clearance efficiency of giant freshwater prawn, Macrobrachium rosenbergii to Lactococcus garvieae. Aquaculture. 219: 111- 121.

Haryani, G.S. \& Hehanussa, P.E. 2002. Masalah, Tantangan, dan Kendala Pengelolaan Danau di Indonesia. P3-TPSLK BPPT \& HSF, Jakarta. hlm. 183- 211.

Suprayitno, T. 1986. Budidaya ikan mas air deras. Jaringan Informasi Perikanan Indonesia. Direktorat Jenderal Perikanan bekerja sama dengan International Development Research Centre. $18 \mathrm{hlm}$.

Sutrisno, Nuryadi, Puspaningsih, D., \& Wardoyo, S.E. 2006. Penanggulangan pencemaran nitrat dan fosfat pada perairan budidaya di perkotaan melalui teknik fitoremediasi. Laporan Hasil Riset, Balai Riset Perikanan Budidaya Air Tawar T.A. 2006. 14 hlm. 